\title{
Mechanical behaviour of cyclic olefin copolymer/exfoliated graphite nanoplatelets nanocomposites foamed by supercritical carbon dioxide
}

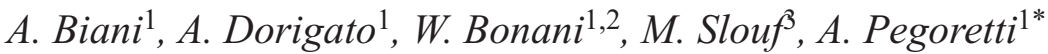 \\ ${ }^{1}$ Department of Industrial Engineering and INSTM Research Unit, University of Trento, via Sommarive 9, 38123 Trento, \\ Italy \\ ${ }^{2}$ Department of Industrial Engineering and BIOtech Research Centre, University of Trento, via delle Regole 101, 38123 \\ Trento, Italy \\ ${ }^{3}$ Institute of Macromolecular Chemistry, Academy of Sciences of the Czech Republic, Heyrovsky sq. 2, 16206 Prague 6, \\ Czech Republic
}

\begin{abstract}
A cycloolefin copolymer matrix was melt mixed with exfoliated graphite nanoplatelets (xGnP) and the resulting nanocomposites were foamed by supercritical carbon dioxide. The density of the obtained foams decreased with the foaming pressure. Moreover, $\mathrm{xGnP}$ limited the cell growth during the expansion process thus reducing the cell diameter (from 1.08 to $0.22 \mathrm{~mm}$ with an $\mathrm{XGnP}$ amount of $10 \mathrm{wt} \%$ at $150 \mathrm{bar}$ ) and increasing the cell density (from 12 to $45 \mathrm{cells} / \mathrm{mm}^{2}$ with a nanofiller content of $10 \mathrm{wt} \%$ at 150 bar). Electron microscopy observations of foams evidenced exfoliation and orientation of the nanoplatelets along the cell walls. Quasi-static compressive tests and tensile creep tests on foams clearly indicated that $\mathrm{xGnP}$ improved the modulus (up to a factor of 10 for a $\mathrm{xGnP}$ content of $10 \mathrm{wt} \%$ ) and the creep stability.
\end{abstract}

Keywords: nanocomposites, foams, graphite nanoplatelets, thermomechanical properties, creep

\section{Introduction}

Polymeric foams are nowadays extensively used in automotive, aerospace, construction and in packaging sectors due to their low density. In fact, a significant reduction in the weight of the components can be reached with polymer foams thus leading to substantial fuel savings in transports with noticeable economic and environmental advantages. Furthermore, a low material density implies natural resources savings, since less material is required for the manufacturing of consumer goods [1]. Due to their elevated thermal insulation power, an important application of polymer foams is represented by insulation of building constructions [2]. From a technological point of view, porous plastics are commonly produced with processing routes involving physical blowing by low boiling hydrocarbons or their halogenated derivatives. Considering that about fifteen billion kilograms of solvents are produced every year worldwide, their usage represents a critical environmental problem because of the noticeable emission of toxic compounds and of polluted waste water production [3]. Therefore, traditional blowing agents (such as pentane, butane, chlorofluoro hydrocarbons) have been withdrawn and replaced by gases like argon, nitrogen and carbon dioxide $[1,4]$. Recently, the usage of supercritical fluids (SFCs) has been considered as a valuable path to produce polymer foams [5-13]. SCFs possess physical properties intermediate between those of gases and fluids. In fact, their density is close 
to that of the liquids and their viscosity is similar to that of gases. At the same time they possess a greater diffusion coefficient with respect to liquids [14]. In addition, close to the critical point, small changes in pressure or temperature result in large changes in density. Polymer matrix foaming with supercritical fluids allows avoiding organic solvents and presents several advantages from a chemical, physical and toxicological points of view. Because of its easy processability, cheapness, non-toxicity and non-flammability, carbon dioxide is the most considered among supercritical fluids $[15,16]$. The usage of carbon dioxide as a solvent could lead to several advantages from a manufacturing, economical and safety points of view.

In the last years, the synthesis of thermoplastic polymers through metallocene-based catalysis attracted the attention of various research groups [17-20]. Particular interest has been devoted to cycloolefin copolymers (COCs) that are amorphous thermoplastics obtained by the copolymerization of norbornene and ethylene. COCs manifest remarkable properties in terms of stiffness, high chemical resistance, good moisture barrier properties, low moisture absorption, and low density. Therefore, COCs are often applied in the production of transparent products (optical data storage, lenses, and sensors), medical and diagnostic devices, food containers, packaging of drugs etc. Considering that the glass-transition temperature $\left(T_{\mathrm{g}}\right)$ of COCs can be tailored by varying the percentage of norbornene [21], various COC grades suitable for specific applications are available on the market. Also polyolefin/COC blends, especially polypropylene/ COC blends [22] and polyethylene/COC blends, have been extensively investigated [23].

It is also well known that the incorporation of nanofillers at concentrations of $5-10 \mathrm{wt} \%$ into a polymer matrix can significantly affect its mechanical behaviour, dimensional stability, thermal degradation and chemical resistance and also gas and solvents impermeability [24]. Moreover, the typical drawbacks related to the use of traditional inorganic microfillers (i.e. embrittlement, loss of transparency, loss of lightness) [25] can be avoided. Some attention has been also devoted to the investigation of COC-based nanocomposites [18, 26].

In the last years, several papers have been published in the open scientific literature on polymer nanocom- posites filled with carbonaceous plate-like nanofillers, such as exfoliated graphite nanoplatelets (xGnP) [27-33]. xGnP nanofiller is constituted by very thin crystalline graphite stacked layers. Due to the honeycomb arrangement of the carbon atoms in the crystal lattice, $\mathrm{xGnP}$ is endowed with exceptional properties in terms of stiffness and strength [34] and it can be therefore used to improve the mechanical properties of a wide range of polymeric materials [27, 33]. The avoidance of $x \mathrm{GnP}$ agglomeration is an essential condition for $\mathrm{xGnP}$ based nanocomposites, because most of the above cited advantages are due to an homogeneous distribution of the nanofiller within the matrix [35, 36]. Moreover, $\mathrm{xGnP}$ has been successfully used to improve barrier properties as well as electrical properties of polymeric materials at low percolation threshold [27]. In fact, its graphitic structure makes it an excellent electrical conductor [37]. In the open literature a few papers can be found on the preparation and physical properties of polymer nanocomposites foamed through supercritical carbon dioxide $\left(\mathrm{scCO}_{2}\right)[9,10]$. For instance, Bhattacharya et al. [5] studied the effect of the foaming parameters (i.e. saturation pressure and temperature, foaming temperature, foaming time and quench temperature) on the physical properties of polypropylene/clay nanocomposites of the prepared materials. In another work of Strauss and D'Souza [12] on supercritical $\mathrm{CO}_{2}$ processed polystyrene nanocomposite foams, it was demonstrated how the foaming process affected both the thermal and morphological behaviour of the prepared materials. Chen et al. [38] performed an experimental and theoretical investigation of the compressive properties of multi-walled carbon nanotubes (MWNTs)/poly (methyl methacrylate) nanocomposite foams, finding that the addition of MWNTs increased both the Young's modulus and the compressive properties of polymer foams.

Quite surprisingly, only marginal attention has been devoted to $\mathrm{xGnP}$ based nanocomposites foamed through supercritical carbon dioxide. The thermal stability of polycarbonate/xGnP nanocomposite foams was studied by Gedler et al. [39], while in another work the dependency of the cellular structure of these nanocomposite foams on the processing parameters (i.e. saturation and foaming temperature) was investigated [40]. Antunes et al. [41] devoted their attention on the microstructural features and the ther- 
mo-mechanical behaviour of polypropylene foams containing $\mathrm{xGnP}$ and expanded through $\mathrm{scCO}_{2}$. A similar topic was presented in the paper of Yeh et al. [42] about the effect of dispersion method and process variables on the properties of supercritical $\mathrm{CO}_{2}$ foamed polystyrene/graphite nanocomposite foams. To the best of our knowledge, no papers dealing with the physical properties of $\mathrm{COC} /$ exfoliated graphite nanoplatelets foamed through $\mathrm{scCO}_{2}$ can be found in the open literature.

Starting from the above considerations, the objective of the present work is to prepare and characterize $\mathrm{COC} / \mathrm{xGnP}$ nanocomposites at various filler concentrations and to foam them by $\mathrm{scCO}_{2}$. A comparison between bulk and foamed samples will be then performed, in order to assess the real effectiveness of $\mathrm{xGnP}$ nanoparticles in improving the mechanical properties of the foams. A detailed analysis of the influence of the foaming processing parameters on the physical properties of the produced materials will be reported.

\section{Experimental part}

\subsection{Materials}

A cycloolefin copolymer (COC) Topas 8007 (melt flow index at $2.16 \mathrm{~kg}, 190{ }^{\circ} \mathrm{C}=2.17 \mathrm{~g} / 10 \mathrm{~min}$, density $=1020 \mathrm{~g} / \mathrm{dm}^{3}$ ) was supplied by Ticona (Florence, Kentucky, USA) in the form of polymer chips. Exfoliated graphite nanoplatelets $\mathrm{xGnP}-\mathrm{M}-5$, (specific surface area of $120 \mathrm{~m}^{2} / \mathrm{g}$, mean diameter of $5 \mu \mathrm{m}$ and thickness of 6-8 $\mathrm{nm}$ [29]) were provided by XG Sciences Inc. (East Lansing, Michigan, USA). Both materials were used as received.

\subsection{Samples preparation}

\subsubsection{Bulk samples preparation}

The filler was melt compounded with COC in a Thermo Haake internal mixer operating at $190^{\circ} \mathrm{C}$, applying a rotors speed of $90 \mathrm{rpm}$. In order to prevent their agglomeration, the nanoparticles were added slowly in the mixer chamber immediately after the complete melting of the COC. The mixing time was set at 15 minutes, enough to promote a complete and homogeneous mixing. This procedure was already reported in our previous paper on COC-fumed silica nanocomposites [18]. In that case, the mixing time was selected after a preliminary characterization of the microstructural properties of the prepared nano- composites. The resulting materials were then hot pressed at $0.2 \mathrm{kPa}$ for 10 minutes at a temperature of $190^{\circ} \mathrm{C}$ in a Carver press, in order to prepare $0.8 \mathrm{~mm}$ thick square sheets.

In this study, $\mathrm{COC} / \mathrm{xGnP}$ bulk nanocomposites were prepared with a filler weight percentage of 1,2, 5 and $10 \mathrm{wt} \%$. Each sample was designated indicating the matrix, the nanofiller type and its weight concentration. For instance, $\mathrm{COC}-\mathrm{xGnP}-1$ denotes the nanocomposite bulk sample with a $\mathrm{xGnP}$ content of $1 \mathrm{wt} \%$.

\subsubsection{Foaming process}

Polymer foams were prepared through a supercritical carbon dioxide treatment at the BIOtech Center of the University of Trento. In Figure 1a, a representation of the $\mathrm{scCO}_{2}$ foaming plant is reported. The equipment is composed by a $\mathrm{CO}_{2}$ tank, a cryostat, a pump and a reaction chamber. The carbon dioxide with a gas purity higher than $99.5 \mathrm{vol} \%$ in liquid/ vapor equilibrium state was supplied in a pressure vessel (60 bar at room temperature) by Messer Italia S.r.l. (Padova, Italy).

Foamed samples were prepared starting from bulk rectangular specimens $5 \mathrm{~mm}$ wide and $20 \mathrm{~mm}$ long. Neat COC copolymer and $\mathrm{COC} / \mathrm{xGnP}$ bulk nanocomposites at various filler contents were placed within a high-pressure reaction vessel (BR-300, Berghof Products + Instruments, Eningen, Germany), consisting of a stainless steel 316Ti vessel with an internal polytetrafluoroethylene (PTFE) liner. The PTFE cylinder with a capacity of $700 \mathrm{ml}$ had a diameter of $60 \mathrm{~mm}$ and a height of $250 \mathrm{~mm}$, with a maximum pressure and temperature services of 200 bar and $260{ }^{\circ} \mathrm{C}$, respectively. The reactor cap was equipped with fluid inlet valve, pressure relief valve and safety valve set at 250 bar. The reactor was also equipped with a submersion thermocouple and a pressure sensor connected to a computer. In order to cool the $\mathrm{CO}_{2}$ lines and pump head, a cryostatic bath with a temperature of $-9^{\circ} \mathrm{C}$ (Model M408-BC, MPM Instruments s.r.l., Bernareggio, MB, Italy) was used.

Once the system was sealed, liquid $\mathrm{CO}_{2}$ was pumped into the reactor and pressurized through a high-performance liquid chromatography (HPLC) pump (Model 426, Alltech, Deerfield, IL, USA) till the supercritical conditions at desired working pressure were reached. The temperature of the reactor was imposed by an electrical heating jacket (BHM 700, 


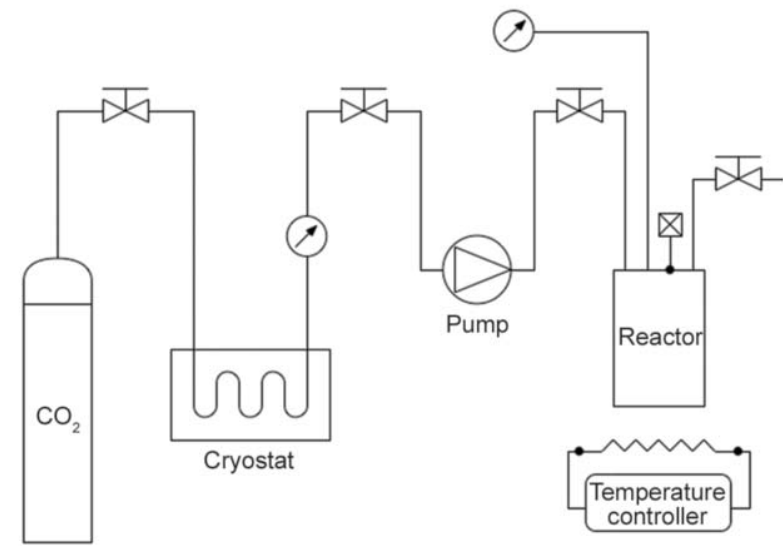

a)

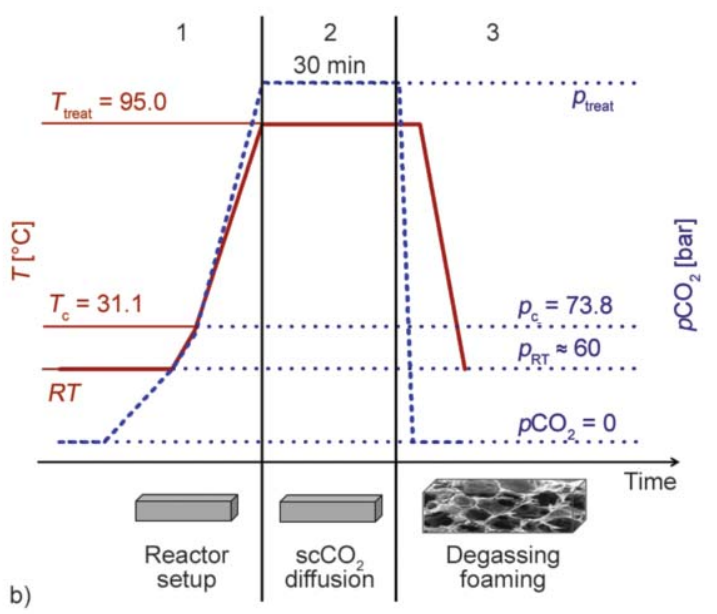

b)

Figure 1. (a) Plant scheme of the foaming process through $\mathrm{scCO}_{2}$, (b) plot of temperature and $\mathrm{CO}_{2}$ pressure conditions in the reactor chamber during the foaming process: stage (1), setup of the treatment conditions; stage (2), 30 min incubation at constant temperature and pressure in $\mathrm{scCO}_{2}$; stage (3), fast depressurization and consequent foaming of the samples

Berghof) run by a BDL-3000 temperature controller (Berghof). In this study, neat COC copolymer and composite samples were exposed to $\mathrm{scCO}_{2}$ at four different pressures $(90,110,130$ and 150 bar) for $30 \mathrm{~min}$. A constant temperature was set at $95^{\circ} \mathrm{C}$ (i.e. about $15^{\circ} \mathrm{C}$ higher than $\mathrm{COC}$ glass transition temperature). Foaming was obtained upon fast depressurization from supercritical to ambient conditions. It is worthwhile to note that the above parameters were optimized in a previous work of this group regarding the preparation and characterization of $\mathrm{COC} /$ fumed silica nanocomposite foams [43].

The plot in Figure 1b outlines the experimental conditions at which the composite materials were subjected during the foaming process in the reactor. During stage (1) bulk composite specimens were introduced into the reactor at $R T$ and the inlet valve was open to place the reactor vessel in communication with the pressurized storage vessel. After the reactor reached an equilibrium state (60 bar at $R T), \mathrm{CO}_{2}$ pressure and reactor temperature were progressively increased to establish supercritical conditions $\left(T_{\mathrm{c}}=\right.$ $31.1^{\circ} \mathrm{C}, p_{\mathrm{c}}=73.8$ bar) and then to meet the desired treatment conditions (namely, $P_{\text {treat }}$ equal to 90,110 , 130 and 150 bar and $T_{\text {treat }}=95^{\circ} \mathrm{C}$ ). During stage (2) composite samples were exposed to $\mathrm{scCO}_{2}$ under constant temperature and pressure for $30 \mathrm{~min}$ to allow for supercritical fluid diffusion into the material. Later in stage (3), the outlet valve was open and $\mathrm{CO}_{2}$ was abruptly released (depressurization rate $50 \mathrm{bar} / \mathrm{min}$ ) to trigger the foaming of the samples. The structure of the foams was then stabilized with the temperature drop from $T_{\text {treat }}$ to ambient conditions.

Foamed samples were designated indicating the matrix, the filler type, the filler content and the foaming pressure. As an example, COC-xGnP-5_e90 indicates

Table 1. List of the prepared samples

\begin{tabular}{|c|c|c|}
\hline Abbreviation & $\begin{array}{c}\text { xGnP content } \\
{[w t \%]}\end{array}$ & $\begin{array}{c}\text { Foaming pressure } \\
\text { [bar] }\end{array}$ \\
\hline $\mathrm{COC}$ & - & - \\
\hline COC-xGnP-1 & 1 & - \\
\hline COC-xGnP-2 & 2 & - \\
\hline COC-xGnP-5 & 5 & - \\
\hline COC-xGnP-10 & 10 & - \\
\hline COC-xGnP-15 & 15 & - \\
\hline COC-xGnP-20 & 20 & - \\
\hline COC_e90 & - & 90 \\
\hline COC-xGnP-1_e90 & 1 & 90 \\
\hline COC-xGnP-2_e90 & 2 & 90 \\
\hline COC-xGnP-5_e90 & 5 & 90 \\
\hline COC-xGnP-10_e90 & 10 & 90 \\
\hline COC_e110 & - & 110 \\
\hline COC-xGnP-1_e110 & 1 & 110 \\
\hline COC-xGnP-2_e110 & 2 & 110 \\
\hline COC-xGnP-5_e110 & 5 & 110 \\
\hline COC-xGnP-10_e110 & 10 & 110 \\
\hline COC_e130 & - & 130 \\
\hline COC-xGnP-1_e130 & 1 & 130 \\
\hline COC-xGnP-2_e130 & 2 & 130 \\
\hline COC-xGnP-5_e130 & 5 & 130 \\
\hline COC-xGnP-10_e130 & 10 & 130 \\
\hline COC_e150 & - & 150 \\
\hline COC-xGnP-1_e150 & 1 & 150 \\
\hline COC-xGnP-2_e150 & 2 & 150 \\
\hline COC-xGnP-5_e150 & 5 & 150 \\
\hline COC-xGnP-10_e150 & 10 & 150 \\
\hline COC-xGnP-15_e150 & 15 & 150 \\
\hline COC-xGnP-20_e150 & 20 & 150 \\
\hline
\end{tabular}


nanocomposite foams with a filler amount of $5 \mathrm{wt} \%$, expanded with depressurization from 90 bar. Table 1 summarizes the list of the prepared samples.

\subsection{Experimental methodologies}

\subsubsection{Microstructure}

Density measurements were carried out by a Gibertini E42 hydrostatic balance, through the displacement method in acetone (density at $20^{\circ} \mathrm{C}$ of $\left.0.792 \mathrm{~g} / \mathrm{cm}^{3}\right)$.

The distribution of the cell size was measured through a Heerbrugg Wild M3Z optical microscope, and a statistical analysis was then performed to determine the mean cell diameter and the relative standard deviation values. The microstructural features of the foam cells were observed through a Carl Zeiss AG Supra 40 FESEM microscope, operating at an acceleration voltage of $5 \mathrm{kV}$. Samples were cryofractured in liquid nitrogen before observations. A Tecnai G2 Spirit Twin FEI TEM microscope operating at an accelerating voltage of $120 \mathrm{kV}$ was used to investigate the silica dispersion within the polymeric matrix of both bulk and foamed materials in bright field (BF) imaging mode. Ultrathin specimens (thickness of about $50 \mathrm{~nm}$ ) were prepared at room temperature by using an Ultracut UCT Leica ultramicrotome.

\subsubsection{Mechanical properties}

Quasi-static tensile tests on the bulk samples were performed through an Instron 4502 tensile testing machine, equipped with a load cell of $1 \mathrm{kN}$. ISO 527 1BA specimens were tested. Elastic modulus was evaluated at $1 \mathrm{~mm} / \mathrm{min}$, through a resistance extensometer with a gage length of $12.5 \mathrm{~mm}$, while tensile tests at break were carried out without the extensometer at a crosshead speed of $5 \mathrm{~mm} / \mathrm{min}$. Mechanical properties of the foamed samples were evaluated at $1 \mathrm{~mm} / \mathrm{min}$ in compression mode on square specimens with a lateral dimension of about $10 \mathrm{~mm}$ and a height of about $3 \mathrm{~mm}$. The Young's modulus $(E)$ of the foamed materials was determined by fitting the stressstrain curves in the initial linear region. All the tests were performed at ambient temperature and at least five specimens were tested for each composition. Creep tests were carried out by a DMA Q800 machine (TA Instruments, USA) at a testing temperature of $30^{\circ} \mathrm{C}$ for 60 minutes under a constant stress of $10 \%$ of the ultimate tensile strength of the neat matrix. Rectangular specimens $5 \mathrm{~mm}$ wide and $1 \mathrm{~mm}$ thick with a gage length of $10 \mathrm{~mm}$ were used to test both bulk samples and polymer foams.

\section{Results and discussion}

\subsection{Morphology}

Density values of the neat $\mathrm{COC}$ and bulk nanocomposites are reported in Table 2. The progressive increase of the density with the nanofiller amount can be explained considering the higher density of $\mathrm{xGnP}$ with respect to the neat matrix. It is also important to evaluate the effect of $\mathrm{xGnP}$ addition on the morphological properties of the prepared foams. Therefore, density measurements were performed also on the foams. In Figure 2 the foams density as a function of the nanofiller content is represented. A systematic

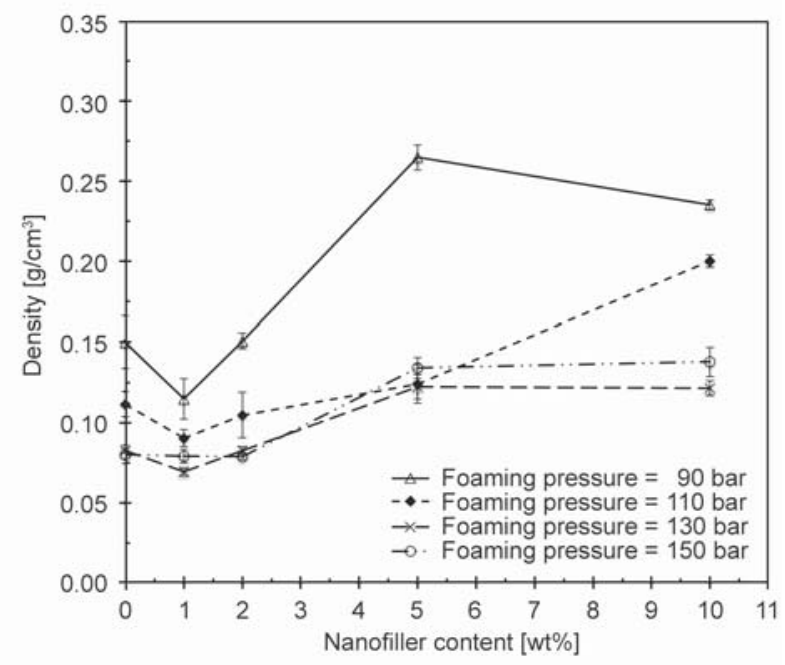

Figure 2. Foams density as a function of the nanofiller content for different foaming pressures

Table 2. Density, elastic modulus $(E)$, stress at break $\left(\sigma_{\mathrm{b}}\right)$, strain at break $\left(\varepsilon_{\mathrm{b}}\right)$ and values of the creep compliance at $3600 \mathrm{~s}$ of bulk samples of neat $\mathrm{COC}$ and relative nanocomposites

\begin{tabular}{|l|c|c|c|c|c|}
\hline \multicolumn{1}{|c|}{ Sample } & $\begin{array}{c}\text { Density } \\
{\left[\mathbf{g} / \mathbf{c m}^{\mathbf{3}}\right]}\end{array}$ & $\begin{array}{c}\boldsymbol{E} \\
{[\mathbf{G P a}]}\end{array}$ & $\begin{array}{c}\boldsymbol{\sigma}_{\mathbf{b}} \\
{[\mathbf{M P a}]}\end{array}$ & $\begin{array}{c}\boldsymbol{\varepsilon}_{\mathbf{b}} \\
{[\mathbf{\%}]}\end{array}$ & $\begin{array}{c}\boldsymbol{D}(\boldsymbol{t}=\mathbf{3 6 0 0}) \\
{\left[\mathbf{M P a}^{-1}\right]}\end{array}$ \\
\hline COC & $1.008 \pm 0.001$ & $2.17 \pm 0.14$ & $59.4 \pm 1.1$ & $5.75 \pm 0.21$ & 1.09 \\
\hline COC-xGnP-1 & $1.012 \pm 0.001$ & $2.39 \pm 0.07$ & $51.2 \pm 2.5$ & $4.92 \pm 0.33$ & 0.83 \\
\hline COC-xGnP-2 & $1.017 \pm 0.001$ & $2.37 \pm 0.10$ & $51.2 \pm 0.8$ & $5.12 \pm 0.18$ & 0.68 \\
\hline COC-xGnP-5 & $1.029 \pm 0.002$ & $2.75 \pm 0.21$ & $44.9 \pm 1.4$ & $4.40 \pm 0.23$ & 0.66 \\
\hline COC-xGnP-10 & $1.054 \pm 0.001$ & $3.36 \pm 0.07$ & $37.7 \pm 1.6$ & $3.22 \pm 0.25$ & 0.60 \\
\hline
\end{tabular}


increase of density with the nanofiller amount can be observed over the whole range of applied pressures. Considering the density variation due to nanofiller addition in bulk samples (see Table 2), it is clear that the density increase in the nanocomposite foams cannot be simply explained by the higher density of $\mathrm{xGnP}$, but also by a morphological change within the

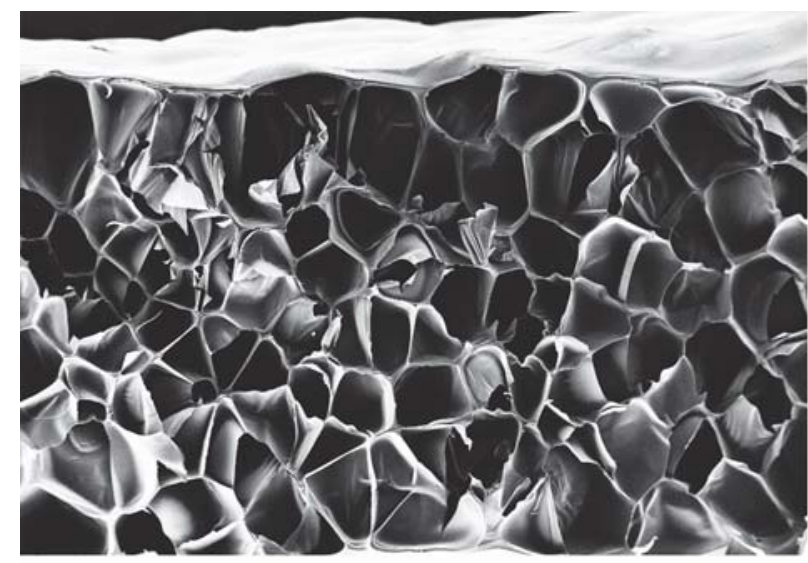

$\longmapsto 200 \mu \mathrm{m}$

a)

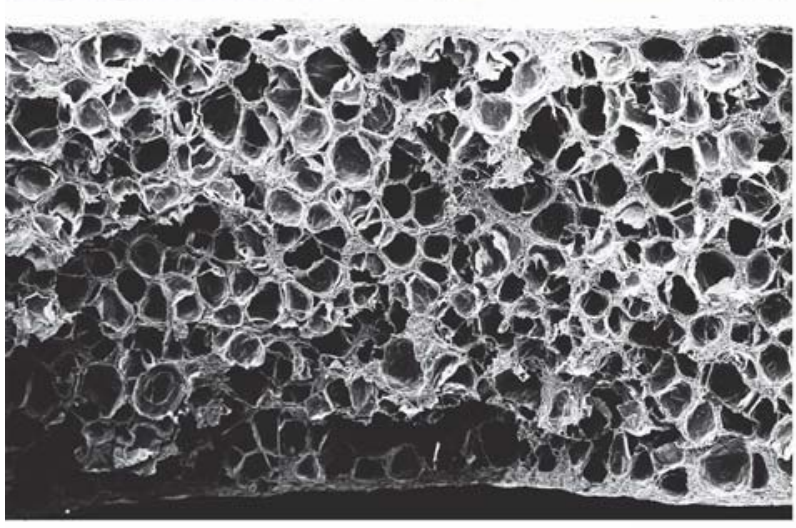

$200 \mu \mathrm{m}$

c)

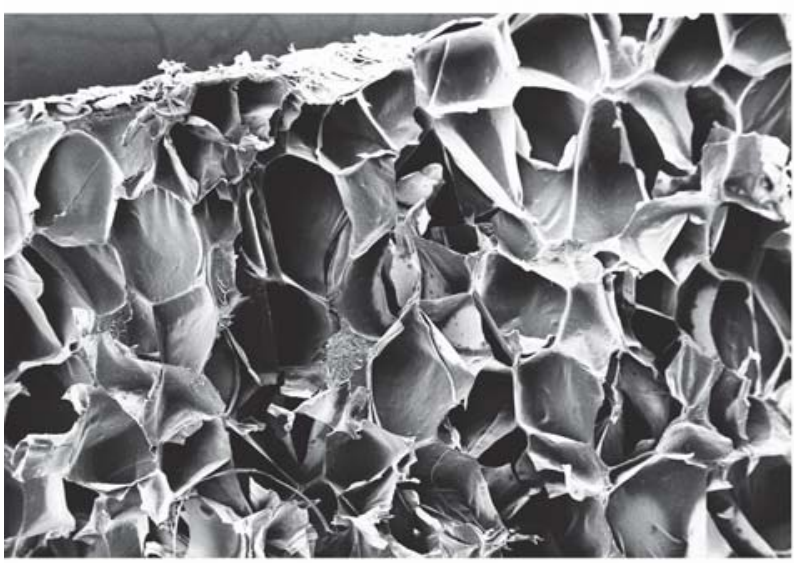

$\longmapsto 200 \mu \mathrm{m}$

e) foam microstructure (i.e. cell density and cell size). In fact, as the foaming pressure increases, a density reduction can be observed for all the compositions. This could be due to the fact that at elevated pressures, the diffusion of the $\mathrm{scCO}_{2}$ within the matrix is favoured and the foaming process is more efficient. To fully understand the density increment of the

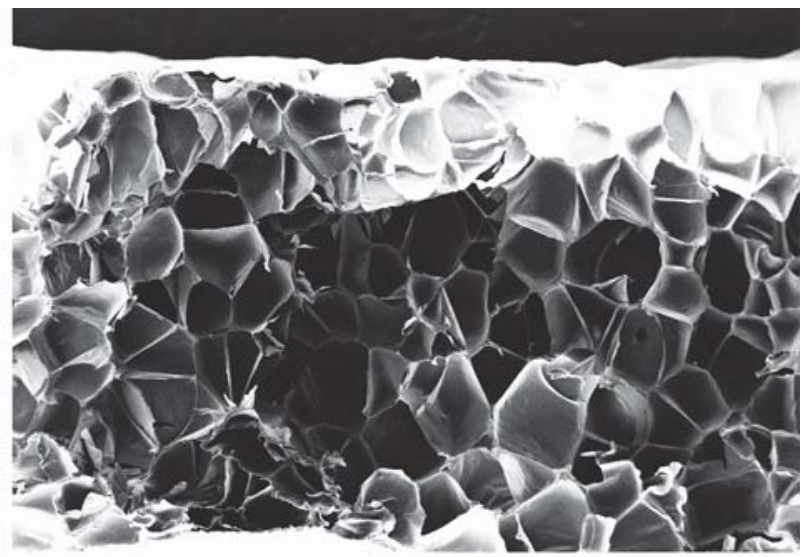

$\longmapsto 200 \mu \mathrm{m}$

b)

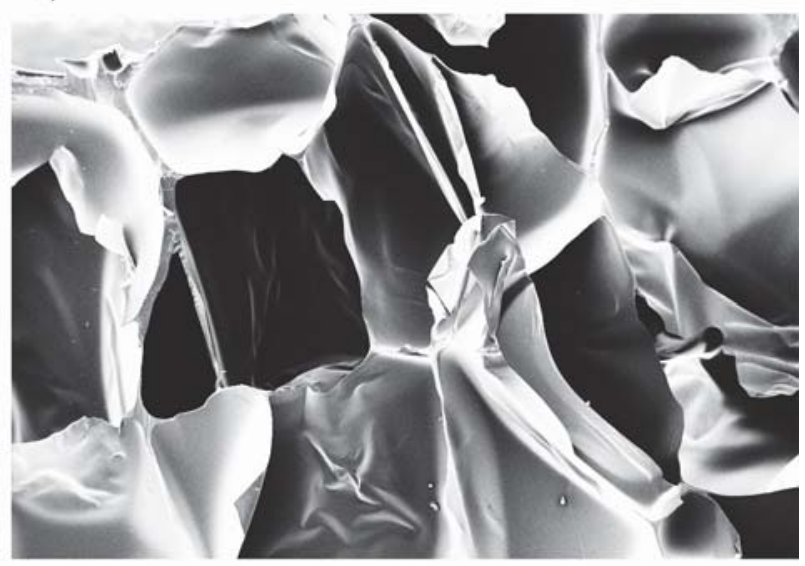

$\longmapsto 200 \mu \mathrm{m}$

d)

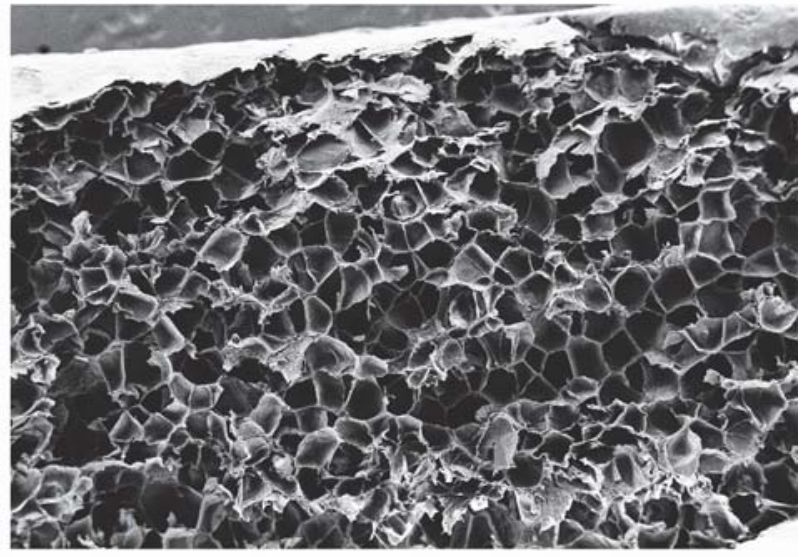

$\longmapsto 200 \mu \mathrm{m}$

Figure 3. FESEM micrographs of the cryofractured surfaces of the foamed samples: (a) COC_e90, (b) COC-xGnP-1_e90, (c) COC-xGnP-10_e90 and (d) COC_e150, (e) COC-xGnP-1_e150, (f) COC-xGnP-10_e150 
foams and the real contribution played by $\mathrm{xGnP}$ addition on the morphology of the prepared cellular solids, FESEM analysis was carried out. In Figure 3, low magnification FESEM micrographs of the foamed nanocomposite materials COC_e90, COCxGnP-1_e90, COC-xGnP-10_e90 (Figure 3a, 3b, and $3 \mathrm{c}$ respectively) and $\mathrm{COC}$ _e150, COC-xGnP-1_e150, COC-xGnP-10_e150 (Figure 3d, 3e and 3f respectively) are compared. All foams present closed cell morphology with a narrow statistical distribution of the cell sizes around an average value. Similar morphological features were observed in a previous work of this group on COC foams filled with nanosilica [43]. From these micrographs, it is immediately evident the role played by the $\mathrm{xGnP}$ content and of the foaming pressure on the morphology of the samples. An increase of the nanofiller amount promotes a reduction of the cell size and a consequent increase of the cell density, while opposite effects can be obtained increasing the foaming pressure. A quantitative evaluation of the cell size distribution was performed by using ImageJ software (U. S. National Institutes of Health, Bethesda, Maryland, USA) [44]. Average cell diameter and cell density [cells $/ \mathrm{mm}^{2}$ ] as a function of the nanofiller content for foams expanded at 90 and 150 bar are reported in Figure 4. The nanofiller introduction hinders the cell growth during the expansion process, thus reducing the cell diameter both at 90 and 150 bar. At the same time, it promotes cell nucleation, increasing the cell density. In previous works of our group it was demonstrated how the nanofiller addition promotes a strong in-

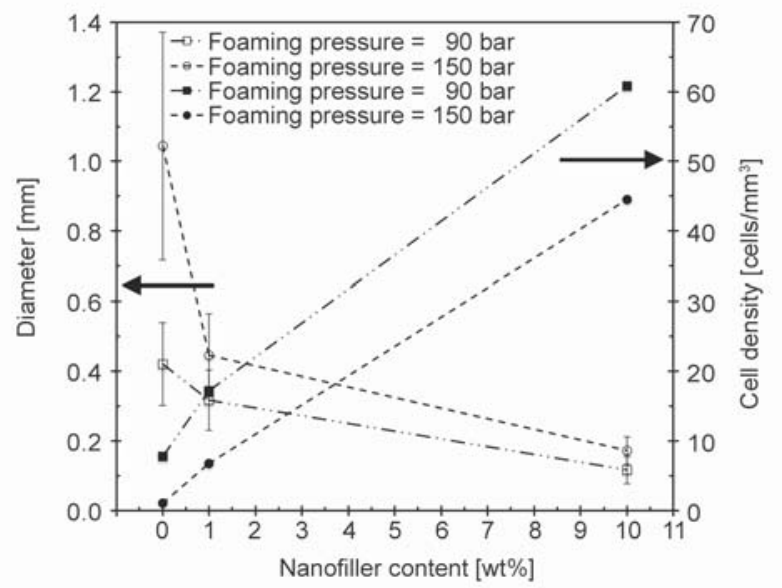

Figure 4. Cell diameter (open symbols) and cell density (full symbols) as a function of the nanofiller content for nanocomposite foams expanded at 90 bar and at 150 bar crease of the polymer viscosity in the molten state $[45,46]$. It is therefore reasonable to assume that $\mathrm{xGnP}$ can enhance the matrix viscosity above the glass transition temperature, thus hindering the expansion process. Moreover, the foaming pressure seems to act in the opposite way. In fact, when $\mathrm{scCO}_{2}$ pressure increases, the cell size increases while the cell density decreases. Therefore, it can be hypothesized that at higher pressure cell growth is favoured over cell nucleation.

A more detailed analysis at higher magnification levels was performed with FESEM equipment, in order to investigate possible exfoliation and/or orientation effects of $\mathrm{xGnP}$ nanoplatelets as a consequence of the foaming process. A FESEM micrograph of COC$\mathrm{xGnP}-10$ bulk sample is reported in Figure 5a. It is possible to observe that $\mathrm{XGnP}$ nanoplatelets are randomly oriented within the matrix, with the presence of agglomerates of stacked lamellae. Moreover, the fracture surface is irregular and jagged. Similar morphological features were also observed by Shadlou et al. [46] and Kalaitzidou et al. [33] on other xGnPbased nanocomposite systems. In Figure $5 b$ and $5 c$ the fracture surfaces of COC-xGnP-10_e90 and COCxGnP-10_e150 are reported. An alignment of xGnP nanoplatelets along the cell walls can be noticed, and this effect is more pronounced at higher foaming pressures, where thinner cell walls can be detected. It is possible that under the selected foaming conditions the $\mathrm{xGnP}$ exfoliation process and alignment along the cell wall was promoted. The evident alignment of $\mathrm{xGnP}$ nanoplatelets at high foaming pressures can be better visualized in FESEM micrographs on COC-xGnP-10_e150 sample at high magnification (see Figure 5d).

In order to perform a deeper investigation of the dispersion level of $\mathrm{xGnP}$ in both bulk and foamed samples, TEM analysis was carried out. In Figure 6, TEM micrographs of bulk and foamed samples are reported. Figures $6 \mathrm{a}$ and $6 \mathrm{~b}$ respectively show $\mathrm{COC}-\mathrm{xGnP}-$ 1 and $\mathrm{COC}-\mathrm{xGnP}-10$ bulk samples, while Figures $6 \mathrm{c}$ and $6 \mathrm{~d}$ show the corresponding foamed samples at 150 bar. In Figure 6a it is clear that bulk samples at low filler amounts are characterized by stacks of $\mathrm{xGnP}$ lamellae with a lateral dimension of less than $50 \mathrm{~nm}$ and a length of about $1 \mu \mathrm{m}$. As already seen in other nanocomposite systems, an increase of the filler loading promotes a strong aggregation of the 


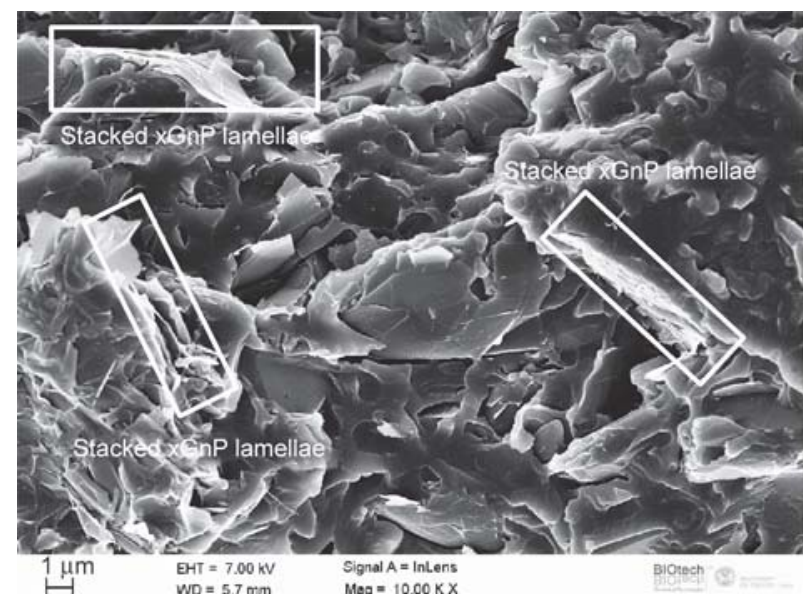

a)

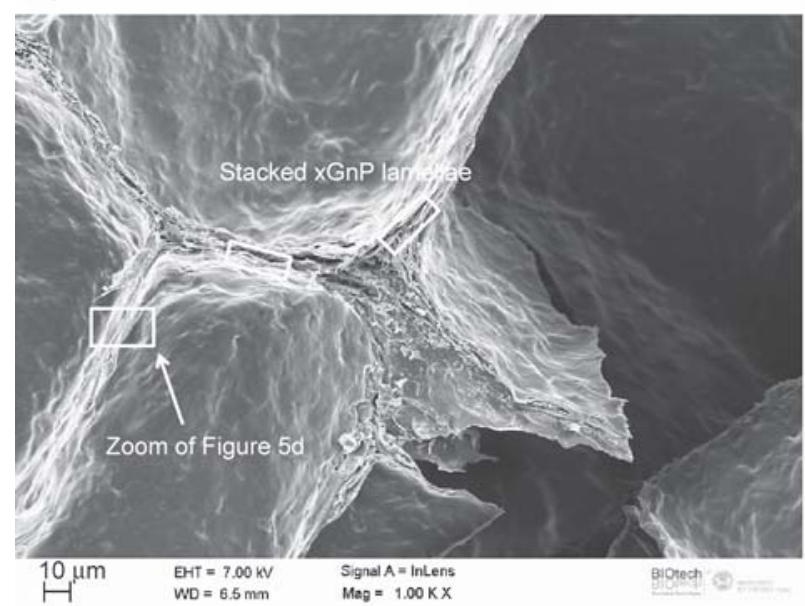

c)

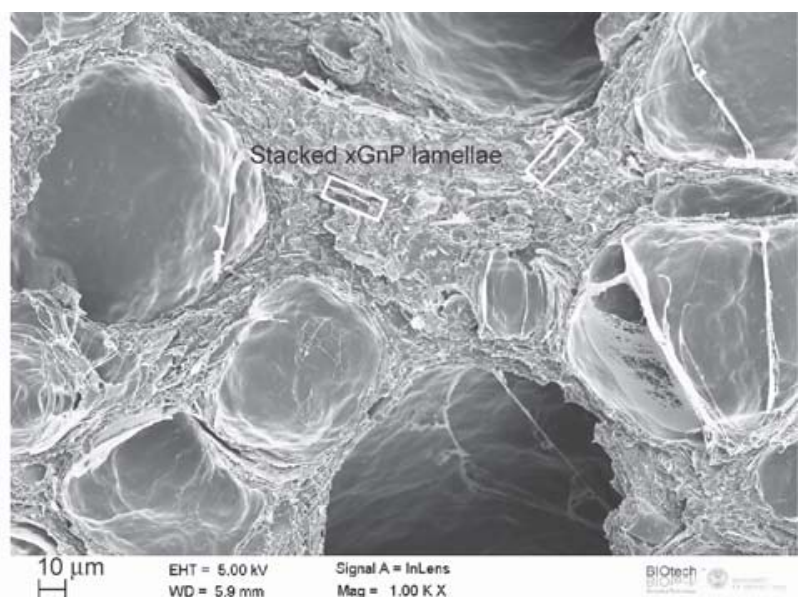

b)

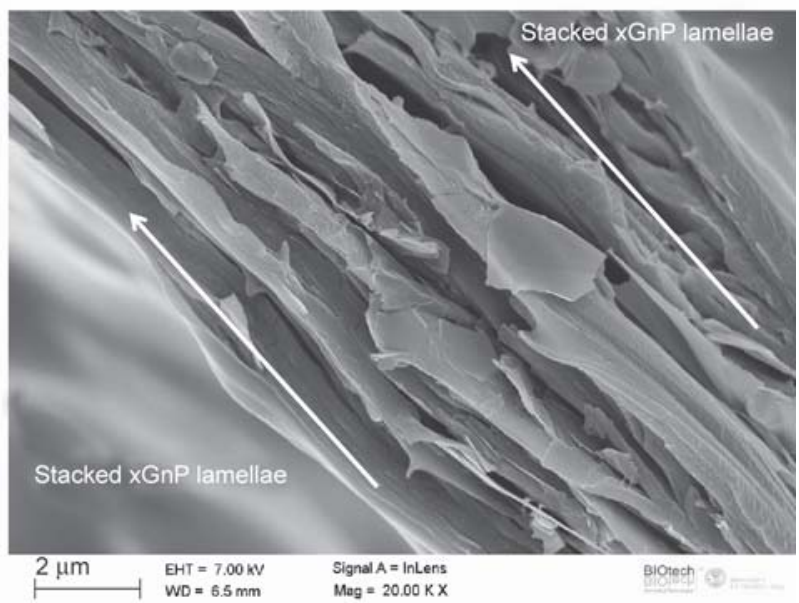

d)

Figure 5. FESEM micrographs of the cryofractured surfaces of the samples: (a) COC-xGnP-10, (b) COC-xGnP-10_e90, (c) and (d) COC-xGnP-10_e150 at different magnifications

nanoplatelets [18] (see Figure 6b). It is interesting to observe that the foaming process leads to an improved exfoliation of $\mathrm{xGnP}$ nanoplatelets. In fact, comparing Figure $6 \mathrm{a}$ and $6 \mathrm{c}$ it is clear that in the foamed samples the agglomeration of the $\mathrm{xGnP}$ stacks is reduced. The same effect can be detected at higher filler loadings (see Figures $6 \mathrm{~b}$ and $6 \mathrm{~d}$ ).

\subsection{Mechanical behaviour}

The effect of the nanofiller loading on the quasi-static tensile properties of the bulk samples was investigated and the most important results are summarized in Table 2 . As frequently observed in nanofilled samples, the $\mathrm{xGnP}$ introduction leads to a noticeable increase of the elastic modulus [33]. In fact, composites with an $\mathrm{xGnP}$ content of $10 \mathrm{wt} \%$ show a $55 \%$ increase in the tensile modulus. The stiffening effect reported in our previous work for the same COC matrix reinforced with silica nanoparticles was less pronounced $[18,43]$. This discrepancy is probably due to the higher stiffness of the $\mathrm{xGnP}$ with respect to silica and to its high aspect ratio which favours the load transfer. As a drawback, the presence of the nanofiller causes an embrittlement of the bulk samples, revealed by the decrease of both the stress and strain at break values $\left(\sigma_{\mathrm{b}}\right.$ and $\left.\varepsilon_{\mathrm{b}}\right)$ as the $\mathrm{xGnP}$ content increases. Most likely the nanofiller aggregation observed at higher filler loadings plays a negative effect on the ultimate properties of the resulting materials.

The effect of $\mathrm{xGnP}$ introduction on the mechanical behaviour of the prepared foams under compression has been also investigated. Representative stressstrain curves from quasi-static compression tests on neat $\mathrm{COC}$ and relative nanocomposites foams at 110 bar are reported in Figure 7. In all the samples, a linear elastic region followed by the yielding of the samples and the plastic deformation of the material is observed. In the third region, a sharp increase of the stress can be detected. A quantitative evaluation of the elastic properties of the foams as a function of 


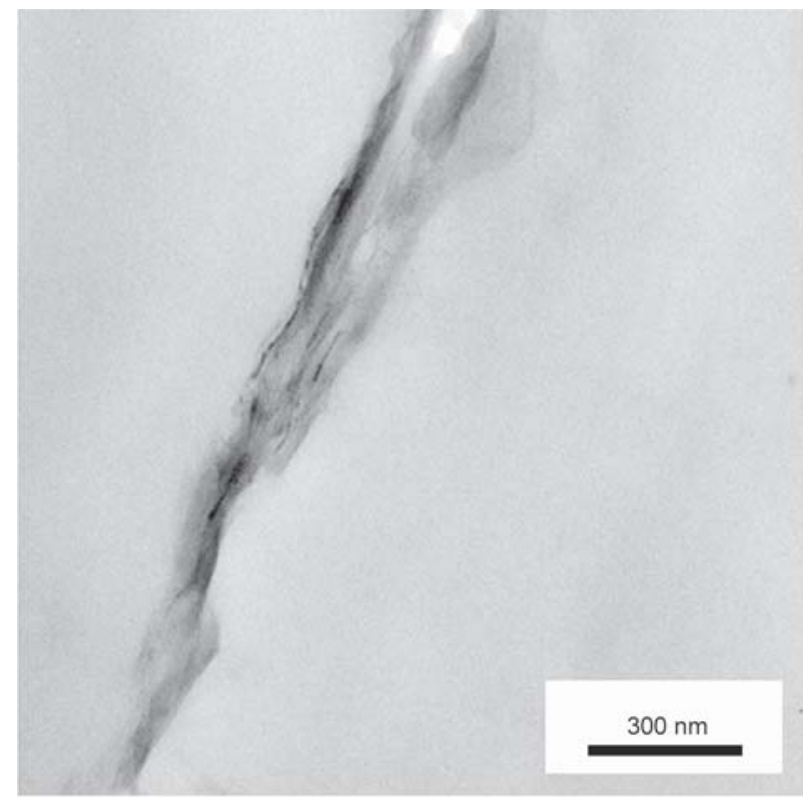

a)

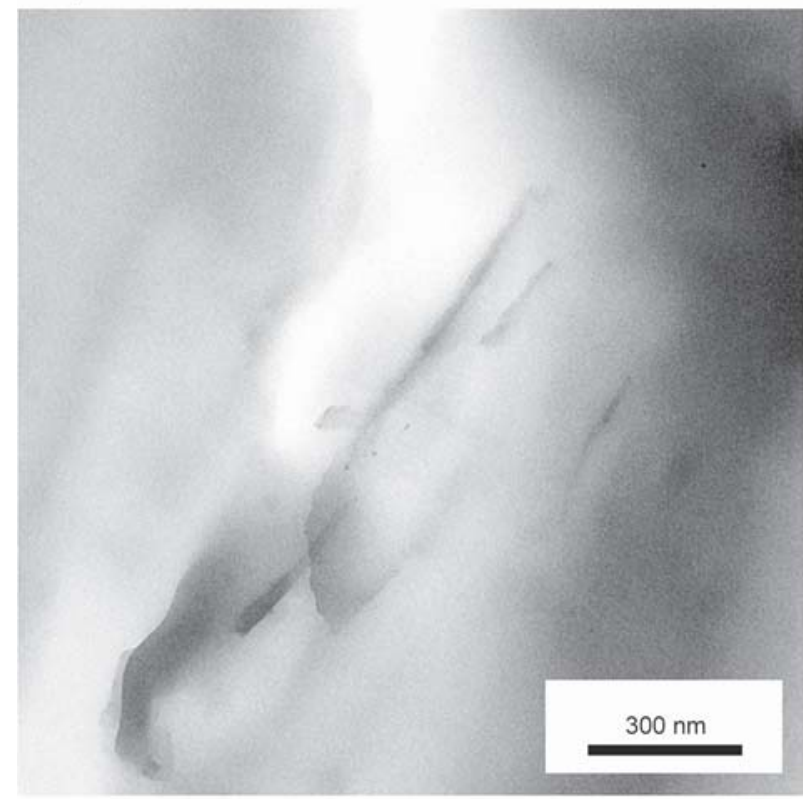

c)

Figure 6. TEM micrographs of the bulk and foamed samples. (a) COC-xGnP-1, (b) COC-xGnP-10, (c) COC-xGnP-1_e150 and (d) COC-xGnP-10_e150.

the nanofiller loading is reported in Figure $8 \mathrm{a}$ and $8 \mathrm{~b}$, where the trends of the modulus and of the specific modulus (i.e. the ratio between the elastic modulus and density) are respectively represented. It is interesting to observe how the nanofiller introduction leads to a remarkable increase of the elastic modulus of the foams, over the whole range of applied foaming pressures. It is worthwhile to observe that the increase of the elastic modulus displayed by the nanofilled foams is noticeably higher than that of the corresponding bulk materials. In fact, with an applied pressure of 150 bar, the COC-xGnP-10_e150 sample

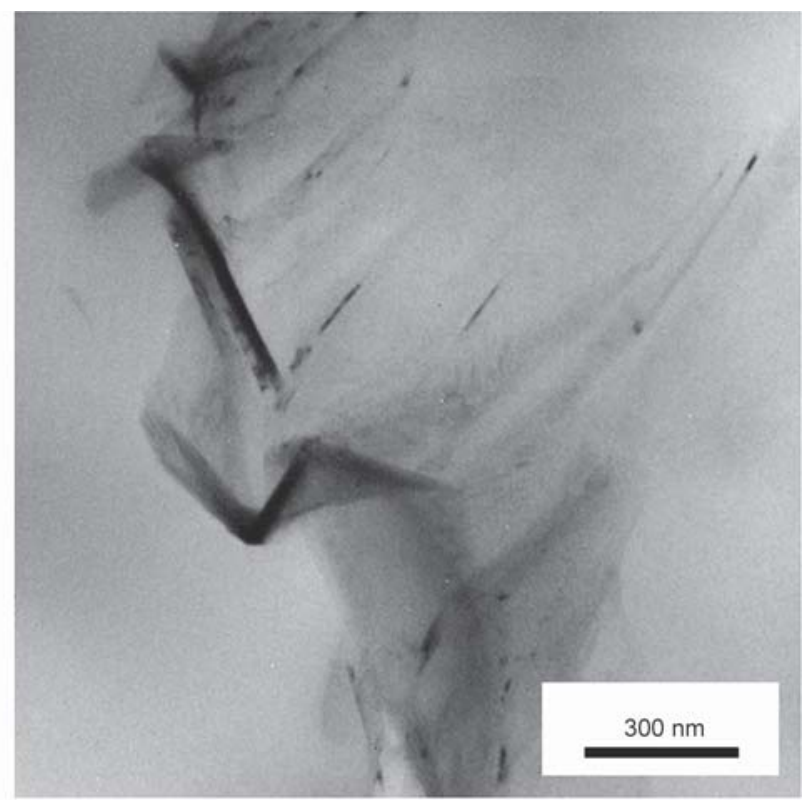

b)

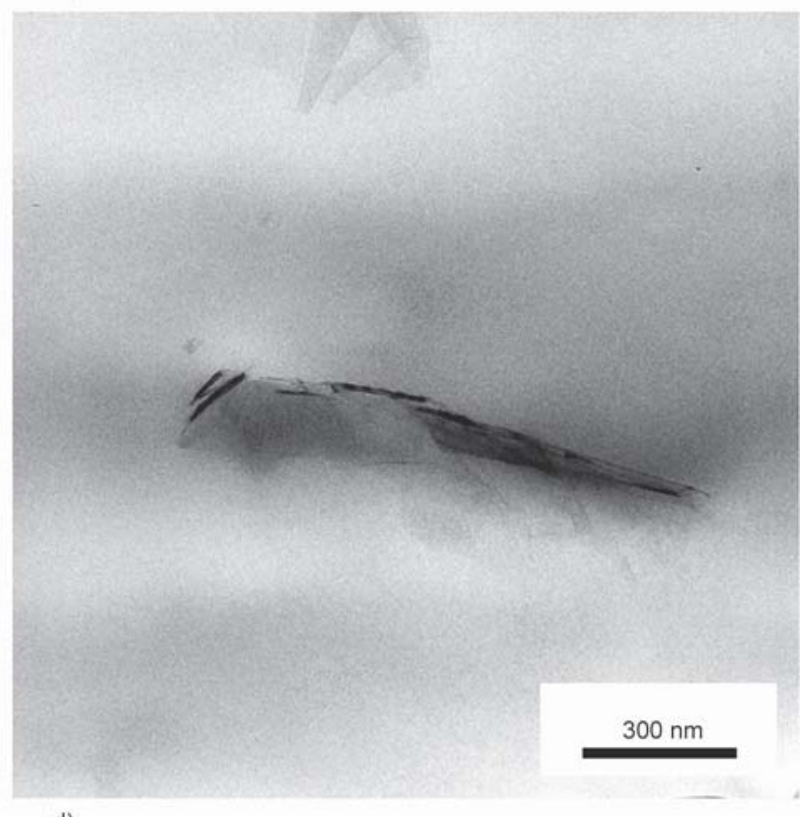

d) manifests an elastic modulus about 10 times higher than the corresponding unfilled foam (see Figure 8a). Even in the case of specific modulus (Figure 8b) the stiffening effect due to nanofiller introduction is evident, especially at higher filler loadings. With an applied pressure of 150 bar, the COC-xGnP-10_e150 sample presents a specific elastic modulus almost 6 times higher than the corresponding unfilled foam. From this example, it is clear that the enhancement of the foams stiffness is partially due to a change in the foams density, but the greater contribution is due to the $\mathrm{xGnP}$ addition. As already observed in the pre- 


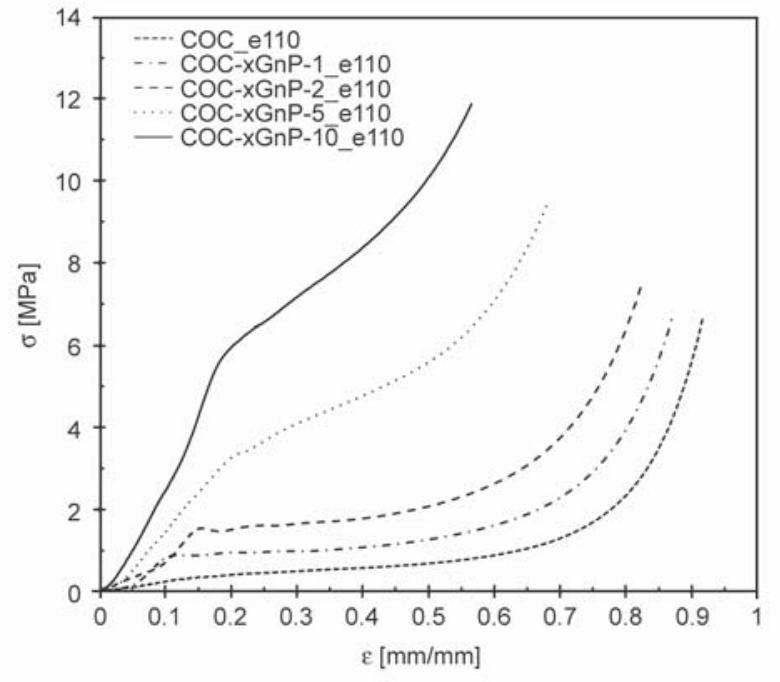

Figure 7. Representative stress-strain curves from quasi-static compression tests on neat $\mathrm{COC}$ and relative nanocomposites foamed at $110 \mathrm{bar}$

vious paragraph, the occurrence of $\mathrm{xGnP}$ exfoliation and orientation given by the foaming pressure can increase the mechanical properties of the matrix itself. However, a more detailed morphological analysis is required to achieve a complete description of the role played by nanofiller morphology on the elastic properties of the nanocomposite foams. The enhancement in the mechanical properties of foams with the nanofiller amount was also observed by Jo et al. [47] in their study about HDPE/clay nanocomposite foams.

In order to confirm the positive effect played by $\mathrm{xGnP}$ nanoplatelets on the mechanical behaviour of bulk and foamed nanocomposites, creep tests were performed. From Table 2 it can be observed how the stabilizing effect due to nanofiller introduction in the

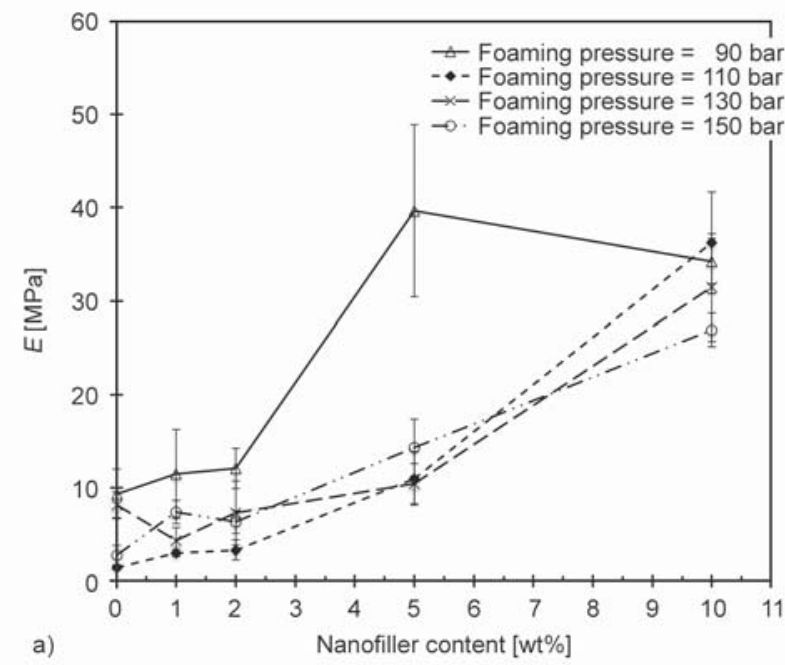

bulk materials leads to an interesting decrease of the creep compliance with respect to the neat COC. For instance, with a nanofiller amount of $10 \mathrm{wt} \%$, the creep compliance at $3600 \mathrm{~s}$ is reduced of about $45 \%$ with respect of the neat COC. This effect is even more pronounced for foamed materials. In Figure 9a creep compliance curves of neat COC and relative nanocomposite foams expanded at 110 bar are reported, while Figure $9 \mathrm{~b}$ shows the creep compliance values at $3600 \mathrm{~s}$. In accordance with elastic modulus results, it can be concluded that the creep stability increases due to nanofiller introduction along the whole range of applied pressures. For instance, considering a pressure of $150 \mathrm{bar}$, the creep compliance at $3600 \mathrm{~s}$ is reduced of about 2.5 times with a nanofiller amount of $10 \mathrm{wt} \%$. Even in this case, the observed stabilizing effect is partly due to a change in the foam density, and a key role is played by $\mathrm{xGnP}$ exfoliation and orientation effects.

\section{Conclusions}

Cycloolefin copolymer/exfoliated graphite nanoplatelets $(\mathrm{xGnP})$ composites were prepared at different filler amounts through a melt compounding process. The resulting materials were foamed through a supercritical carbon dioxide based process by varying the foaming pressure. Bulk and foamed materials were then characterized from a morphological and a mechanical points of view, in order to understand the role of the nanofiller amount and of the foaming pressure on their physical properties. It was observed how the $\mathrm{xGnP}$ introduction systematically increased both bulk (from 1.01 up to $1.05 \mathrm{~g} / \mathrm{cm}^{3}$ with a $\mathrm{xGnP}$

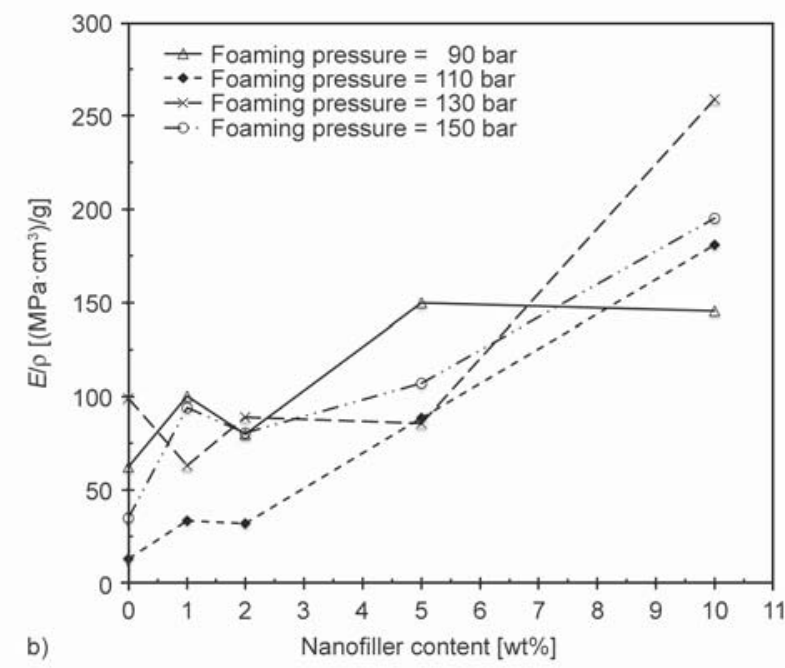

Figure 8. (a) Elastic modulus $(E)$, (b) normalized elastic modulus over density $(E / \rho)$ of the foamed samples 

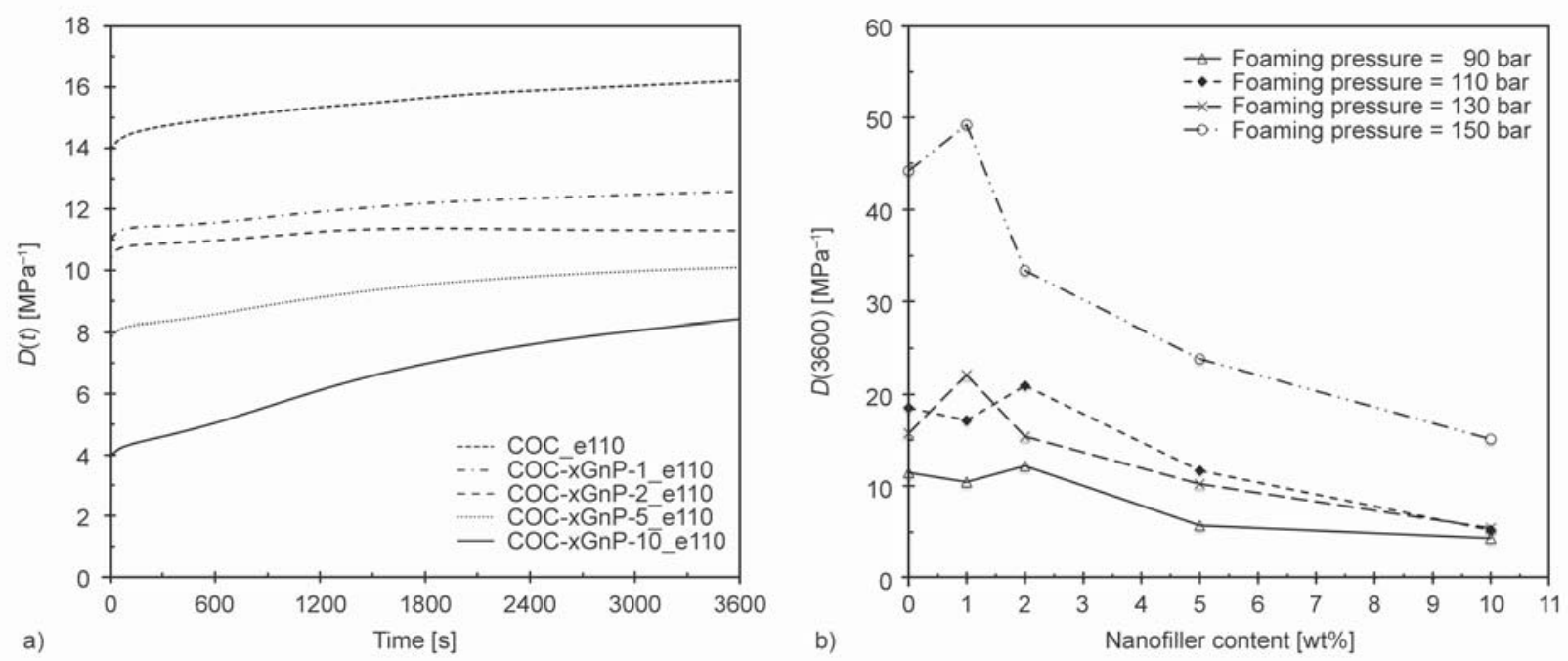

Figure 9. (a) Creep compliance curves of neat COC and relative nanocomposites at a foaming pressure of 110 bar. (b) Creep compliance at $3600 \mathrm{~s}$ as a function of the nanofiller content for nanocomposite foams at different foaming pressures.

amount of $10 \mathrm{wt} \%$ ) and foam density (from $0.15 \mathrm{up}$ to $0.24 \mathrm{~g} / \mathrm{cm}^{3}$ with a $\mathrm{xGnP}$ amount of $10 \mathrm{wt} \%$ at 90 bar), while elevated foaming pressures promoted a consistent density reduction. Microstructural analysis on the resulting foams highlighted a progressive increase of the mean cell size with the foaming pressure, accompanied by an evident exfoliation and orientation of the nanoplatelets along the cell walls direction. These microstructural effects were responsible for an important improvement of the mechanical properties of the foams, with a progressive enhancement of the elastic properties with $\mathrm{xGnP}$ amount (with a pressure of 150 bar, the COC-xGnP-10_e150 sample has an elastic modulus about 10 times higher than the corresponding unfilled foam), and also the creep stability was noticeably improved. Concluding, foaming process of $\mathrm{COC}$ nanocomposites through supercritical carbon dioxide could represent an effective way to prepare low density polymeric foams characterized by higher mechanical stability with respect to the corresponding neat COC copolymer.

\section{Acknowledgements}

TEM microscopy at the Institute of Macromolecular Chemistry was supported by projects TE01020118 (Technology Agency of the CR) and POLYMAT LO1507 (Ministry of Education, Youth and Sports of the CR, program NPU I).

\section{References}

[1] Kozlowski M.: Lightweight plastic materials. InTech, Rijeka (2012).
[2] Papadopoulos A. M.: State of the art in thermal insulation materials and aims for future developments. Energy and Buildings, 37, 77-86 (2005).

DOI: $10.1016 /$ j.enbuild.2004.05.006

[3] Cooper A. I.: Porous materials and supercritical fluids. Advanced Materials, 15, 1049-1059 (2003). DOI: $10.1002 /$ adma.200300380

[4] Lee S-T., Scholz D. P. K.: Polymeric foams: Technology and developments in regulation, process, and products. CRC Press, Boca Raton (2008).

[5] Bhattacharya S., Gupta R. K., Jollands M., Bhattacharya S. N.: Foaming behavior of high-melt strength polypropylene/clay nanocomposites. Polymer Engineering and Science, 49, 2070-2084 (2009).

DOI: $10.1002 /$ pen. 21343

[6] Gendron R., Champagne M. F., Tatibouet J., Bureau M. N.: Foaming cyclo-olefin copolymers with carbon dioxide. Cellular Polymers, 28, 1-23 (2009).

[7] Han X., Koelling K. W., Tomasko D. L., Lee L. J.: Continuous microcellular polystyrene foam extrusion with supercritical $\mathrm{CO}_{2}$. Polymer Engineering and Science, 42, 2094-2106 (2002).

DOI: $10.1002 /$ pen. 11100

[8] Han X., Zeng C., Lee L. J., Koelling K. W., Tomasko D. L.: Extrusion of polystyrene nanocomposite foams with supercritical $\mathrm{CO}_{2}$. Polymer Engineering and Science, 43, 1261-1275 (2003). DOI: $10.1002 /$ pen.10107

[9] Jiang X-L., Bao J-B., Liu T., Zhao L., Xu Z-M., Yuan W-K.: Microcellular foaming of polypropylene/clay nanocomposites with supercritical carbon dioxide. Journal of Cellular Plastics, 45, 515-538 (2009). DOI: $\underline{10.1177 / 0021955 X 09339470}$ 
[10] Nam P. H., Maiti P., Okamoto M., Kotaka T., Nakayama T., Takada M., Ohshima M., Usuki A., Hasegawa N., Okamoto H.: Foam processing and cellular structure of polypropylene/clay nanocomposites. Polymer Engineering and Science, 42, 1907-1918 (2002). DOI: $10.1002 /$ pen. 11083

[11] Otsuka T., Taki K., Ohshima M.: Nanocellular foams of PS/PMMA polymer blends. Macromolecular Materials and Engineering, 293, 78-82 (2008).

DOI: $10.1002 /$ mame.200700257

[12] Strauss W., D’Souza N. A.: Supercritical $\mathrm{CO}_{2}$ processed polystyrene nanocomposite foams. Journal of Cellular Plastics, 40, 229-241 (2004). DOI: $10.1177 / 0021955 X 04043720$

[13] Xu Z-M., Jiang X-L., Liu T., Hu G-H., Zhao L., Zhu ZN., Yuan W-K.: Foaming of polypropylene with supercritical carbon dioxide. The Journal of Supercritical Fluids, 41, 299-310 (2007).

DOI: 10.1016/j.supflu.2006.09.007

[14] McHugh M., Krukonis V.: Supercritical fluid extraction: Principles and practice. Elsevier, Amsterdam (2013).

[15] Nalawade S. P., Picchioni F., Janssen L. P. B. M.: Supercritical carbon dioxide as a green solvent for processing polymer melts: Processing aspects and applications. Progress in Polymer Science, 31, 19-43 (2006). DOI: 10.1016/j.progpolymsci.2005.08.002

[16] Yeo S-D., Kiran E.: Formation of polymer particles with supercritical fluids: A review. The Journal of Supercritical Fluids, 34, 287-308 (2005).

DOI: $10.1016 /$ j.supflu.2004.10.006

[17] Arndt M., Beulich I.: $\mathrm{C}_{1}$-symmetric metallocenes for olefin polymerisation, 1. Catalytic performance of $\left[\mathrm{Me}_{2} \mathrm{C}\left(3{ }^{\text {tert }} \mathrm{BuCp}\right)(\mathrm{Flu})\right] \mathrm{ZrCl}_{2}$ in ethene/norbornene copolymerisation. Macromolecular Chemistry and Physics, 199, 1221-1232 (1998).

DOI: 10.1002/(SICI)1521-3935(19980601)199:6<1221 $\because$ AID-MACP1221>3.0.CO;2-2

[18] Dorigato A., Pegoretti A., Fambri L., Slouf M., Kolař́ik J.: Journal of Applied Polymer Science, 119, 3393 3402 (2011).

DOI: $10.1002 /$ app.32988

[19] Ou C-F., Hsu M-C.: Preparation and properties of cycloolefin copolymer/silica hybrids. Journal of Applied Polymer Science, 104, 2542-2548 (2007).

DOI: $10.1002 /$ app. 25983

[20] Ou C-F., Hsu M-C.: Preparation and characterization of cyclo olefin copolymer (COC)/silica nanoparticle composites by solution blending. Journal of Polymer Research, 14, 373-378 (2007). DOI: $10.1007 / \mathrm{s} 10965-007-9119-5$

[21] Forsyth J. F., Scrivani T., Benavente R., Marestin C., Pereña J. M.: Thermal and dynamic mechanical behavior of ethylene/norbornene copolymers with medium norbornene contents. Journal of Applied Polymer Science, 82, 2159-2165 (2001).

DOI: $10.1002 / a p p .2063$
[22] Pegoretti A., Kolařík J., Fambri L., Penati A.: Polypropylene/cycloolefin copolymer blends: Effects of fibrous phase structure on tensile mechanical properties. Polymer, 44, 3381-3387 (2003). DOI: 10.1016/s0032-3861(03)00248-9

[23] Kolařík J., Pegoretti A., Fambri L., Penati A.: High-density polyethylene/cycloolefin copolymer blends, Part 2: Nonlinear tensile creep. Polymer Engineering and Science, 46, 1363-1373 (2006).

DOI: $10.1002 /$ pen.20580

[24] Ajayan P. M., Schadler L. S., Braun P. V.: Nanocomposite science and technology. Wiley, New York (2006).

[25] Bondioli F., Dorigato A., Fabbri P., Messori M., Pegoretti A.: High-density polyethylene reinforced with submicron titania particles. Polymer Engineering and Science, 48, 448-457 (2008).

DOI: $10.1002 /$ pen.20973

[26] Dorigato A., Pegoretti A., Migliaresi C.: Physical properties of polyhedral oligomeric silsesquioxanes-cycloolefin copolymer nanocomposites. Journal of Applied Polymer Science, 114, 2270-2279 (2009).

DOI: 10.1002/app.30593

[27] Drzal L. T., Fukushima H.: Exfoliated graphite nanoplatelets $(\mathrm{xGnP})$ : A carbon nanotube alternative. in 'Proceedings of NSTI Nanotechnology Conference and Trade Show, Boston, USA' Vol 1, 170-173 (2006).

[28] Kim S., Do I., Drzal L. T.: Thermal stability and dynamic mechanical behavior of exfoliated graphite nanoplatelets-LLDPE nanocomposites. Polymer Composites, 31, 755-761 (2010).

DOI: $10.1002 / p c .20781$

[29] Pedrazzoli D., Pegoretti A.: Expanded graphite nanoplatelets as coupling agents in glass fiber reinforced polypropylene composites. Composites Part A: Applied Science and Manufacturing, 66, 25-34 (2014). DOI: $10.1016 /$ j.compositesa.2014.06.016

[30] Persson H., Yao Y., Klement U., Rychwalski R.: A simple way of improving graphite nanoplatelets (GNP) for their incorporation into a polymer matrix. Express Polymer Letters, 6, 142-147 (2012).

DOI: $10.3144 /$ expresspolymlett.2012.15

[31] Ferreira C. I., Dal Castel C., Oviedo M. A. S., Mauler R. S.: Isothermal and non-isothermal crystallization kinetics of polypropylene/exfoliated graphite nanocomposites. Thermochimica Acta, 553, 40-48 (2013). DOI: $10.1016 /$ j.tca.2012.11.025

[32] Akın D., Kasgoz A., Durmus A.: Quantifying microstructure, electrical and mechanical properties of carbon fiber and expanded graphite filled cyclic olefin copolymer composites. Composites Part A: Applied Science and Manufacturing, 60, 44-51 (2014). DOI: $10.1016 /$ j.compositesa.2014.01.008

[33] Kalaitzidou K., Fukushima H., Drzal L. T.: Mechanical properties and morphological characterization of exfoliated graphite-polypropylene nanocomposites. Composites Part A: Applied Science and Manufacturing, 38, 1675-1682 (2007).

DOI: 10.1016/j.compositesa.2007.02.003 
[34] Pierson H. O.: Handbook of carbon, graphite, diamonds and fullerenes: Processing, properties and applications. William Andrew, Norwich (2012).

[35] Liu W-W., Chai S-P., Mohamed A. R., Hashim U.: Synthesis and characterization of graphene and carbon nanotubes: A review on the past and recent developments. Journal of Industrial and Engineering Chemistry, 20, 1171-1185 (2014).

DOI: $10.1016 /$ j.jiec.2013.08.028

[36] Mittal G., Dhand V., Rhee K. Y., Park S-J., Lee W. R.: A review on carbon nanotubes and graphene as fillers in reinforced polymer nanocomposites. Journal of Industrial and Engineering Chemistry, 21, 11-25 (2015). DOI: $10.1016 /$ j.jiec.2014.03.022

[37] Singh V., Joung D., Zhai L., Das S., Khondaker S. I., Seal S.: Graphene based materials: Past, present and future. Progress in Materials Science, 56, 1178-1271 (2011). DOI: $10.1016 /$ j.pmatsci.2011.03.003

[38] Chen L., Schadler L. S., Ozisik R.: An experimental and theoretical investigation of the compressive properties of multi-walled carbon nanotube/poly(methyl methacrylate) nanocomposite foams. Polymer, 52, 2899-2909 (2011).

DOI: 10.1016/j.polymer.2011.04.050

[39] Gedler G., Antunes M., Realinho V., Velasco J. I.: Thermal stability of polycarbonate-graphene nanocomposite foams. Polymer Degradation and Stability, 97, 1297 1304 (2012).

DOI: $10.1016 /$ j.polymdegradstab.2012.05.027

[40] Gedler G., Antunes M., Realinho V., Velasco J. I.: Novel polycarbonate-graphene nanocomposite foams prepared by $\mathrm{CO}_{2}$ dissolution. IOP Conference Series: Materials Science and Engineering, 31, 012008/1-012008/9 (2002).

DOI: $\underline{10.1088 / 1757-899 X / 31 / 1 / 012008}$
[41] Antunes M., Gedler G., Velasco J. I.: Multifunctional nanocomposite foams based on polypropylene with carbon nanofillers. Journal of Cellular Plastics, 49, 259279 (2013).

DOI: $10.1177 / 0021955 X 13477433$

[42] Yeh S-K., Huang C-H., Su C-C., Cheng K-C., Chuang T-H., Guo W-J., Wang S-F.: Effect of dispersion method and process variables on the properties of supercritical $\mathrm{CO}_{2}$ foamed polystyrene/graphite nanocomposite foam. Polymer Engineering and Science, 53, 2061-2072 (2013). DOI: $10.1002 /$ pen.23468

[43] Pegoretti A., Dorigato A., Biani A., Slouf M.: Cyclic olefin copolymer-silica nanocomposites foams. Journal of Materials Science, 51, 3907-3916 (2016).

DOI: $10.1007 / \mathrm{s} 10853-015-9710-9$

[44] Dorigato A., Pegoretti A., Penati A.: Linear low-density polyethylene/silica micro-and nanocomposites: Dynamic rheological measurements and modelling. Express Polymer Letters, 4, 115-129 (2010).

DOI: $10.3144 /$ expresspolymlett.2010.16

[45] Pedrazzoli D., Dorigato A., Pegoretti A.: Monitoring the mechanical behaviour of electrically conductive polymer nanocomposites under ramp and creep conditions. Journal of Nanoscience and Nanotechnology, 12, 40934102 (2012).

DOI: $10.1166 /$ jnn.2012.6219

[46] Shadlou S., Ahmadi-Moghadam B., Taheri F.: The effect of strain-rate on the tensile and compressive behavior of graphene reinforced epoxy/nanocomposites. Materials and Design, 59, 439-447 (2014).

DOI: $10.1016 /$ j.matdes.2014.03.020

[47] Jo C., Naguib H. E.: Constitutive modeling of HDPE polymer/clay nanocomposite foams. Polymer, 48, 33493360 (2007). DOI: $10.1016 /$ j.polymer.2007.03.056 